\title{
Nomenclatural novelties for the Euro+Med flora
}

\author{
Enrico Banfi ${ }^{1}$, Gabriele Galasso $^{1^{*}}$, Fabrizio Bartolucci ${ }^{2}$
}

\begin{abstract}
Today's plant phylogeny more and more deals with ranks from the genus down, so changes in current taxonomy and nomenclature are frequently requested. For this reason, referring to the Euro+Med flora, we take here into account 20 taxa and recover the following forgotten nomenclatural combinations: Bidens atrosanguinea (Hook.) Regel, B. formosa (Bonato) Sch.Bip., B. sulphurea (Cav.) Sch.Bip., and $B$. tinctoria (Nutt.) Baill. ex Daydon. Moreover we propose the new names Agrostis linkii Banfi, Galasso \& Bartolucci, Bidens selenactis Banfi, Galasso \& Bartolucci, Bidens sweetiana Banfi, Galasso \& Bartolucci, and the new combinations Achnatherum paradoxum (L.) Banfi, Galasso \& Bartolucci, A. virescens (Trin.) Banfi, Galasso \& Bartolucci, Agrostis linkii Banfi, Galasso \& Bartolucci subsp. prostrata (Hack. \& Lange) Banfi, Galasso \& Bartolucci, Bidens atkinsoniana (Douglas ex Lind1.) Banfi, Galasso \& Bartolucci, B. basalis (A.Dietr.) Banfi, Galasso \& Bartolucci, B. gladiata (Walter) Banfi, Galasso \& Bartolucci, B. lanceolata (L.) Banfi, Galasso \& Bartolucci, Calamagrostis arenaria (L.) Roth subsp. arundinacea (Husn.) Banfi, Galasso \& Bartolucci, Prunus $\times$ hybrida (Schmidt) Galasso, Banfi \& Bartolucci, Solanum aethiopicum L. subsp. anguivi (Lam.) Banfi, Galasso \& Bartolucci, S. macrocarpon L. subsp. dasyphyllum (Schumach. \& Thonn.) Banfi, Galasso \& Bartolucci, S. melongena L. subsp. insanum (L.) Banfi, Galasso \& Bartolucci, and Trisetaria argentea (Willd.) Banfi, Galasso \& Soldano.
\end{abstract}

Key words: Achnatherum, Agrostis, Bidens, Calamagrostis, nomenclature, Prunus, Solanum, taxonomy, Trisetaria.

Riassunto - Combinazioni nuove, combinazioni rivalutate e nomi nuovi per la flora d'Italia e d'Europa.

Gli odierni studi filogenetici in campo botanico stanno ponendo crescente attenzione ai taxa di rango generico e di rango inferiore. Da ciò nasce la frequente necessità di modificare i modelli sistematici, i quali richiedono a loro volta nuovi assestamenti della tassonomia corrente e della nomenclatura. Il presente contributo prende in considerazione 20 taxa di interesse europeo e mediterraneo per i

\footnotetext{
${ }^{1}$ Sezione di Botanica, Museo di Storia Naturale di Milano, Corso Venezia 55, 20121 Milano, Italia.

E-mail: parajubaea@gmail.com

${ }^{2}$ Scuola di Bioscienze e Medicina Veterinaria, Università di Camerino - Centro Ricerche Floristiche dell'Appennino, Parco Nazionale del Gran Sasso e Monti della Laga, San Colombo, 67021 Barisciano (AQ), Italia.

E-mail: fabrizio.bartolucci@gmail.com

* Corresponding author: gabriele.galasso@comune.milano.it

(C) 2017 Enrico Banfi, Gabriele Galasso \& Fabrizio Bartolucci
}

Received: 5 October 2017

Accepted for publication: 30 November 2017 quali 1) vengono recuperate 4 vecchie combinazioni: Bidens atrosanguinea (Hook.) Regel, B. formosa (Bonato) Sch.Bip., B. sulphurea (Cav.) Sch.Bip. e B. tinctoria (Nutt.) Baill. ex Daydon; 2) sono istituiti 3 nomi nuovi: Agrostis linkii Banfi, Galasso \& Bartolucci, Bidens selenactis Banfi, Galasso \& Bartolucci e Bidens sweetiana Banfi, Galasso \& Bartolucci; 3) si propongono le seguenti 13 nuove combinazioni: Achnatherum paradoxum (L.) Banfi, Galasso \& Bartolucci, A. virescens (Trin.) Banfi, Galasso \& Bartolucci, Agrostis linkii Banfi, Galasso \& Bartolucci subsp. prostrata (Hack. \& Lange) Banfi, Galasso \& Bartolucci, Bidens atkinsoniana (Douglas ex Lindl.) Banfi, Galasso \& Bartolucci, B. basalis (A.Dietr.) Banfi, Galasso \& Bartolucci, B. gladiata (Walter) Banfi, Galasso \& Bartolucci, B. lanceolata (L.) Banfi, Galasso \& Bartolucci, Calamagrostis arenaria (L.) Roth subsp. arundinacea (Husn.) Banfi, Galasso \& Bartolucci, Prunus $\times$ hybrida (Schmidt) Galasso, Banfi \& Bartolucci, Solanum aethiopicum L. subsp. anguivi (Lam.) Banfi, Galasso \& Bartolucci, S. macrocarpon L. subsp. dasyphyllum (Schumach. \& Thonn.) Banfi, Galasso \& Bartolucci, S. melongena L. subsp. insanum (L.) Banfi, Galasso \& Bartolucci e Trisetaria argentea (Willd.) Banfi, Galasso \& Soldano.

Parole chiave: Achnatherum, Agrostis, Bidens, Calamagrostis, nomenclatura, Prunus, Solanum, tassonomia, Trisetaria.

\section{INTRODUCTION}

Research advancements in plant phylogeny continuously open new horizons on systematics, especially from the rank of genus downward, making necessary from time to time to reassess taxonomy and nomenclature where this is considered better representative of the evolution pattern. This primary purpose must be pursued through the provisions on names as established by the ICN (McNeill et al., 2012). For the subjects discussed here papers have recently shown that some genera must be merged as well as, in the case of crop-wild relationship, subordination is needed at subspecies rank, as already proposed by Harlan \& de Wet (1971) and followed by most authors (e.g., Bartolucci et al., 2017; Galasso et al., 2017). Particularly when the descent is demonstrably linear, that means the crop selection took place starting from and proceeding within a single wild species without external genomial contributions, it is preferable subordinating at subspecies rank the wild to the crop or vice versa, depending on the names priority. In fact most crops and wild relatives had been described independently at the rank of species, both because of an unquestionable morphological distinctness and because of the historical prematureness of evolution and domestication ideas. 
In this paper seventeen taxa both native and alien to Italy (see: Bartolucci et al., 2016, 2018; Galasso et al., 2016), Europe and the Mediterranean area (Euro+Med, 2006 onwards) are taken into account. Moreover we have included three tropical crops of Solanum, currently being tested in the Italian as well as European agriculture, whose wild ancestors are well known but, based on what was said before, need taxonomic adjustment.

\section{ASTERACEAE}

Phylogenetic investigations on the Coreopsideae (Kim et al., 1999; Crawford et al., 2001, 2009; Kimball \& Crawford, 2004; Crawford \& Mort, 2005; Mort et al., 2008) highlighted several genera, including Coreopsis L. and Cosmos Cav., within which Bidens L. is evidently nested, making it clear that we can not keep them separate. Both Bidens [1753] and Coreopsis [1753] have the same priority over remaining genera needing to opt for Bidens as that chosen by Baillon (1886), who first united them (Art. 11.5. of ICN). Concerning the Euro+Med area, two new names and eight combinations are shown below: four of the last already exist, the other are proposed here as new.

Bidens atkinsoniana (Douglas ex Lindl.) Banfi, Galasso \& Bartolucci, comb. nov. Bas.: Coreopsis atkinsoniana Douglas ex Lindl., Edward's Bot. Reg., 16: pl. 1376. 1830 [Mar-Dec 1830].

Note: some authors (e.g., Strother, 2006) consider this species as a synonym of $B$. tinctoria.

Bidens atrosanguinea (Hook.) Regel (三 Cosmos diversifolius Otto ex Knowles \& Westc. var. atrosanguineus Hook. $\equiv$ Cosmos atrosanguineus (Hook.) Voss).

Bidens basalis (A.Dietr.) Banfi, Galasso \& Bartolucci, comb. nov. Bas.: Calliopsis basalis A.Dietr., Allg. Gartenzeitung (Otto \& Dietrich), 3 (42): 329 (-331). 1835 [17 Oct 1835]. (三Coreopsis basalis (A.Dietr.) S.F.Blake).

Bidens formosa (Bonato) Sch.Bip., Bot. Voy. Herald [Seemann], 7-8: 307. 1856. Bas.: Coreopsis formosa Bonato, Pisaura Automorpha e Coreopsis formosa: XXI (-XXVII, pl. II). 1793 [Sep-Oct 1793]. (= Cosmos bipinnatus Cav., non Bidens bipinnata L. $\equiv$ Georgia bipinnata (Cav.) Spreng.).

Note: the binomial of Schultz Bipontinus is to be understood as new combination of the Bonato's epithet, not as a replaced name of Cavanilles' one (Art. 41.4. and Ex. 10. of ICN). We are convinced that Schultz knew the reference of Steudel's Nomenclator Botanicus (1840: 425), who reports Coreopsis formosa Bonato as synonym of Cosmos (sub Cosmus) bipinnatus Cav.

Bidens gladiata (Walter) Banfi, Galasso \& Bartolucci, comb. nov. Bas.: Coreopsis gladiata Walter, Fl. Carol. [Walter]: 215. 1788 [Apr-Jun 1788]. (= Coreopsis angustifolia Aiton, non C. angustifolia L.).

Bidens lanceolata (L.) Banfi, Galasso \& Bartolucci, comb. nov. Bas.: Coreopsis lanceolata L., Sp. Pl., 2: 908. 1753 [1 May 1753].

Bidens selenactis Banfi, Galasso \& Bartolucci, nom. nov. Bas.: Coreopsis verticillata L., Sp. Pl., 2: 907 (-908). 1753 [1 May 1753]., non Bidens verticillata L., Sp. Pl., 2: 833. 1753 [1 May 1753].
Etymology: latinized greek translation of 'Moonbeam', one of the most popular cultivar of this species.

Bidens sulphurea (Cav.) Sch.Bip. (三 Cosmos sulphureus Cav. = Cosmos aurantiacus Klatt, non Bidens aurantiaca Colenso).

Bidens sweetiana Banfi, Galasso \& Bartolucci, nom. nov. Bas.: Coreopsis grandiflora Hogg ex Sweet, Brit. Fl. Gard. [Sweet], 2: pl. 175. 1827 [1 Jun 1825-Apr 1827]., non Bidens grandiflora Balb., Cat. Pl. (Balbis), 1812: 19. 1812.

Etymology: dedicated to Robert Sweet (1783-1835) who validated the name proposed by Thomas Hogg (1777-1855) for this species.

Bidens tinctoria (Nutt.) Baill. ex Daydon (三 Calliopsis tinctoria (Nutt.) DC. $\equiv$ Coreopsis tinctoria Nutt. $\equiv$ Diplosastera tinctoria (Nutt.) Tausch).

\section{POACEAE}

The submersion of the genera Chaetopogon Janch. and Ammophila Host respectively into Agrostis L. and Calamagrostis Adans. is made necessary according to the phylogenetic classification by Soreng et al. $(2015,2017)$. Regarding Piptatherum sect. Virescentia Roshev. ex Freitag ( $P$. paradoxum and $P$. virescens), Romaschenko et al. (2012) studied evolution and systematics of Stipeae based on analysis of multiple chloroplast loci, ITS, and lemma micromorphology. They confirm that no doubt the two species in question lie among other old world taxa in the same clade as Achnatherum bromoides (L.) P.Beauv. and $A$. calamagrostis (L.) P.Beauv. (Romaschenko et al., 2010), where A. calamagrostis represents the lectotype of its genus. In particular, $P$. paradoxum and $P$. virescens result to be sister of $A$. bromoides ( 85 bootstrap from the analysis of plastid data). Authors conclude by saying that «The sister relationship of $A$. bromoides and Piptatherum sect. Virescentia is more plausible since the taxa share dark and coriaceous lemmas with a blunt callus, persistent awns, and similar habitats.». Based on these data we propose to transfer $P$. paradoxum and $P$. virescens to the genus Achnatherum, as already suggested by Kellogg (2015: 217). Finally, Trisetaria argentea "(Vill.)" Banfi \& Soldano (1996) is an invalid name as uncorrectly established referring to a non-existent Villars' basionym, therefore we propose again the same combination on the correct reference.

Achnatherum paradoxum (L.) Banfi, Galasso \& Bartolucci, comb. nov. Bas.: Agrostis paradoxa L., Sp. Pl. 1: 62. 1753 [1 May 1753]. (三 Milium paradoxum (L.) L. $\equiv$ Oryzopsis paradoxa (L.) Nutt. $\equiv$ Piptatherum paradoxum (L.) P.Beauv. $\equiv$ Stipa paradoxa (L.) Raspail).

Achnatherum virescens (Trin.) Banfi, Galasso \& Bartolucci, comb. nov. Bas.: Urachne virescens Trin., Fund. Agrost. (Trinius): 110. 1820 [Jan 1820]. (三 Milium paradoxum (L.) L. var. virescens (Trin.) Fiori $\equiv$ Milium virescens (Trin.) Borbás $\equiv$ Oryzopsis paradoxa (L.) Nutt. var. virescens (Trin.) K.Richt. $\equiv$ Oryzopsis virescens (Trin.) Beck $\equiv$ Piptatherum virescens (Trin.) Boiss.).

Agrostis linkii Banfi, Galasso \& Bartolucci, nom. nov. Bas.: Chaeturus fasciculatus Link, J. Bot. (Schrader), 2 (2): 313. 1800 [Apr 1800]. (三 Chaetopogon fasciculatus 
(Link) Hayek, non Agrostis fasciculata (Kunth) Roem. \& Schult.).

Etymology: dedicated to Johann H. F. Link (17671851), author of the basionym.

Note: the genus Chaeturus Link [1799] is illegitimate because of the previous homonym Chaiturus (= Chaeturus) Willd. [1787] (Lamiaceae).

Agrostis linkii Banfi, Galasso \& Bartolucci subsp. prostrata (Hack. \& Lange) Banfi, Galasso \& Bartolucci, comb. nov. Bas.: Chaeturus prostratus Hack. \& Lange, Vidensk. Naturhist. Foren. Kjøbenhavn, 1877-1878: 223. 1878. (三 Chaetopogon fasciculatus (Link) Hayek subsp. prostratus (Hack. \& Lange) M.Laínz $\equiv$ Chaeturus fasci-culatus Link subsp. prostratus (Hack. \& Lange) Paunero).

Calamagrostis arenaria (L.) Roth subsp. arundinacea (Husn.) Banfi, Galasso \& Bartolucci, comb. nov. Bas.: Ammophila arenaria (L.) Link var. arundinacea Husn., Graminées, 1: 19. 1896 [May 1896]. (三 Ammophila arenaria (L.) Link subsp. arundinacea (Husn.) H.Lindb.) (= Psamma australis Mabille $\equiv$ Ammophila arenaria (L.) Link subsp. australis (Mabille) M.Laínz).

Note: the epithet arundinacea is due to Host (Icon. Descr. Gram. Austriac., 4: 24 (pl. 41). 1809.), but it is illegitimate according to Art. 52.2.(e) of ICN. The same epithet was legitimately taken by Husnot 87 years later (Art. 58.1. of ICN). According to Art. 41.4. of ICN, it has to be treated as a new combination based on Husnot's name.

Trisetaria argentea (Willd.) Banfi, Galasso \& Soldano, comb. nov. Bas.: Avena argentea Willd., Enum. Pl. [Willdenow] 1: 125. 1809 [Apr 1809]. (三 Trisetum argenteum (Willd.) Roem. \& Schult. $\equiv$ Trisetum distichophyllum (Vill.) P.Beauv. var. argenteum (Willd.) Ducommun; - Trisetaria argentea Banfi \& Soldano, nom. nud.).

\section{ROSACEAE}

For the horticultural hybrid between almond (Prunus dulcis (Mill.) D.A.Webb) and peach (P. persica (L.) Batsch), recently reported as casual alien to Italy $(<$ http://www.floraitaliae.actaplantarum.org/viewtopic. php? $\mathrm{t}=43473 \& \mathrm{p}=278405 \# \mathrm{p} 278405>$, retrieved on 4 October 2017), after an exhaustive review of the available synonyms Rehder (1922) established the combination Prunus xamygdalo-persica (Weston) Rehder. He noted that the most ancient binomial with priority is Amygdalus amygdalo-persica Weston [1770] which however lacks description, but, in his opinion, it is usable on the basis of an earlier [1768] Duhamel's name Amygdalo-Persica subsequently picked-up by Poiret to designate a rankless variant of Amygdalus communis L. Rehder adds: "If Weston's name should be rejected for the reason that it lacks a description, Schneider's $P$. persico-amygdala based on Amygdalus Persico-amygdala Reichenb. [1832] would be the correct name, for Schmidt's A. hybrida [1822] [...] cannot be transferred to Prunus on account of Prunus hybrida Quetierii Carr. (sic!) [...], a supposed hybrid between Prunus Armeniaca L. and P. Persica Batsch.". Actually, the obstacle due to Carrière's name (Mouillefert, 1892) does not exist according to Art. 23.1. of ICN; moreover Art. H.10.2. prevents the use of epithets made by parental epithets united by hyphen considering them formulae, not true epithets. In our case this excludes any adoption of most reported synonyms including the Rehder's combination under Prunus (i.e., amygdalo-persica, communi-persica, and persico-amygdala), while allows we to recover the name of Schmidt Amygdalus $\times$ hybrida as basionym.

Prunus $\times$ hybrida (Schmidt) Galasso, Banfi \& Bartolucci, comb. nov. Bas.: Amygdalus hybrida Schmidt (pro hybr.), Österr. Allg. Baumz., 4: 27 (-28, pl. 207). 1822. (= Amygdalus communis L. var. persicoides Ser. $\equiv$ Prunus amygdalus Batsch var. persicoides (Ser.) Koehne $\equiv$ P. $\times$ persicoides (Ser.) M.Vilm. \& Bois $=P$. dulcis (Mill.) D.A.Webb $q \times P$. persica (L.) Batsch $\delta^{\lambda} ;-P$. $\times$ amygdalopersica (Weston) Rehder, nom. inv.).

\section{SOLANACEAE}

Three species are here involved: Solanum aethiopicum L. (scarlet eggplant), S. macrocarpon L. (gboma eggplant) and S. melongena L. (common eggplant). Solanum anguivi (Africa) is the wild ancestor of S. aethiopicum as highlited for the first time by Lester \& Niakan (1986), then confirmed by the following authors (e.g., Knapp et al., 2013; Plazas et al., 2014). About the descent of the crop $S$. macrocarpon from the wild $S$. dasyphyllum (Africa) the same is true as for the previous species (Knapp et al., 2013; Plazas et al., 2014). Finally, S. insanum (India) in the past has been forgotten and confused with other wild relatives of the Melongena group, especially $S$. incanum L.; it was also underestimated as the true ancestor of the common eggplant (Ranil et al., 2017).

Solanum aethiopicum L. subsp. anguivi (Lam.) Banfi, Galasso \& Bartolucci, comb. nov., stat. nov. Bas.: Solanum anguivi Lam., Tabl. Encycl., 2 (3, 1): 23. 1794 [10 Apr 1794].

Solanum macrocarpon L. subsp. dasyphyllum (Schumach. \& Thonn.) Banfi, Galasso \& Bartolucci, comb. nov., stat. nov. Bas.: Solanum dasyphyllum Schumach. \& Thonn., Beskr. Guin. Pl.: 126. 1827.

Solanum melongena L. subsp. insanum (L.) Banfi, Galasso \& Bartolucci, comb. nov., stat. nov. Bas.: Solanum insanum L., Mant. Pl.: 46. 1767 [15-31 Oct 1767]. (三 Solanum melongena L. var. insanum (L.) Prain).

\section{REFERENCES}

Baillon H., 1886 - Histoire des plantes. Librairie Hachette \& $C^{i e}$, Paris, 8.

Banfi E. \& Soldano A., 1996 - Dati tassonomici e nomenclaturali su Poaceae dell'Europa e del Mediterraneo. Atti della Società Italiana di Scienze Naturali e del Museo Civico di Storia Naturale in Milano, 135 (2) (1994): 379-387.

Bartolucci F., Peruzzi L., Galasso G. \& Conti F., 2016 Checklist aggiornata della flora vascolare autoctona d'Italia. In: Minilavori della Riunione scientifica del Gruppo per la Floristica, Sistematica ed Evoluzione. 21-22 ottobre 2016, Roma. Domina G. \& Peruzzi L. (eds.). Notiziario della Società Botanica Italiana, 0: 29-30. 
Bartolucci F., Domina G., Adorni M., Alessandrini A., Ardenghi N. M. G., Banfi E., Baragliu G. A., Bernardo L., Bertolli A., Biondi E., Carotenuto L., Casavecchia S., Cauzzi P., Conti F., Crisanti M. A., D’Amico F. S., Di Cecco V., Di Martino L., Faggi G., Falcinelli F., Forte L., Galasso G., Gasparri R., Ghillani L., Gottschlich G., Guzzon F., Harpke D., Lastrucci L., Lattanzi E., Maiorca G., Marchetti D., Medagli P., Olivieri N., Pascale M., Passalacqua N. G., Peruzzi L., Picollo S., Prosser F., Ricciardi M., Salerno G., Stinca A., Terzi M., Viciani D., Wagensommer R. P. \& Nepi C., 2017 Notulae to the Italian native vascular flora: 3. Italian Botanist, 3: 29-48. doi: 10.3897/ib.3.13200

Bartolucci F., Peruzzi L., Galasso G., Albano A., Alessandrini A., Ardenghi N. M. G., Astuti G., Bacchetta G., Ballelli S., Banfi E., Barberis G., Bernardo L., Bouvet D., Bovio M., Cecchi L., Di Pietro R., Domina G., Fascetti S., Fenu G., Festi F., Foggi F., Gallo L., Gottschlich G., Gubellini L., Iamonico D., Iberite M., Jiménez-Mejías P., Lattanzi E., Marchetti D. Martinetto E., Masin R. R., Medagli P., Passalacqua N. G., Peccenini S., Pennesi R., Pierini B., Poldini L., Prosser F., Raimondo F. M., Roma-Marzio F., Rosati L., Santangelo A., Scoppola A., Scortegagna S., Selvaggi A., Selvi F., Soldano A., Stinca A., Wagensommer R. P., Wilhalm T. \& Conti F., 2018 - An updated checklist of the vascular flora native to Italy. Plant Biosystems, 152 (2): in press.

Crawford D. J., Kimball R. T. \& Tadesse M., 2001 - The generic placement of a morphologically enigmatic species in Asteraceae: evidence from ITS sequences. Plant Systematics and Evolution, 228 (1-2): 63-69. doi: $10.1007 / \mathrm{s} 006060170037$

Crawford D. J. \& Mort M. E., 2005 - Phylogeny of Eastern North American Coreopsis (Asteraceae-Coreopsideae): insights from nuclear and plastid sequences, and comments on character evolution. American Journal of Botany, 92 (2): 330-336. doi: 10.3732/ajb.92.2.330

Crawford D. J., Tadesse M., Mort M. E., Kimball R. T. \& Randle C. P., 2009 - Coreopsideae. In: Systematics, evolution and biogeography of Compositae. Funk V. A., Susanna A., Stuessy T. F. \& Bayer R. J. (eds.). International Association for Plant Taxonomy, Vienna: 713-730.

Euro+Med, 2006 onwards - Euro+Med PlantBase. The information resource for Euro-Mediterranean plant diversity. Available from: <http://www.emplantbase. org/home.html $>$ (retrieved on 29 September 2017).

Galasso G., Bartolucci F., Peruzzi L., Ardenghi N. M. G., Banfi E., Celesti-Grapow L. \& Conti F., 2016 - Checklist aggiornata della flora vascolare alloctona d'Italia. In: Minilavori della Riunione scientifica del Gruppo per la Floristica, Sistematica ed Evoluzione. 21-22 ottobre 2016, Roma. Domina G. \& Peruzzi L. (eds.). Notiziario della Società Botanica Italiana, 0: 49-50.

Galasso G., Domina G., Ardenghi N. M. G., Assini S., Banfi E., Bartolucci F., Bigagli V., Bonari G., Bonivento E., Cauzzi P., D’Amico F. S., D'Antraccoli M., Dinelli D., Ferretti G., Gennai M., Gheza G., Guiggi A., Guzzon F., Iamonico D., Iberite M., Latini M., Lonati M., Mei G., Nicolella G., Olivieri N., Peccenini
S., Peraldo G., Perrino E. V., Prosser F., Roma-Marzio F., Russo G., Selvaggi A., Stinca A., Terzi M., Tison J.-M., Vannini J., Verloove F., Wagensommer R. P., Wilhalm T. \& Nepi C., 2017 - Notulae to the Italian alien vascular flora: 3. Italian Botanist, 3: 49-71. doi: $10.3897 / \mathrm{ib} .3 .13126$

Harlan J. R. \& de Wet J. M. J., 1971 - Toward a rational classification of cultivated plants. Taxon, 20 (4): 509517. doi: $10.2307 / 1218252$

Kellogg E. A., 2015 - The families and genera of vascular plants. Vol. 13. Springer, Cham, Heidelberg, New York, Dordrecht, London.

Kim S.-C., Crawford D. J., Tadesse M., Berbee M., Ganders F. R., Pirseyedi M. \& Esselman E. J., 1999 - ITS Sequences and Phylogenetic Relationships in Bidens and Coreopsis (Asteraceae). Systematic Botany, 24 (3): 480-493. doi: 10.2307/2419701

Kimball R. T. \& Crawford D. J., 2004 - Phylogeny of Coreopsideae (Asteraceae) using ITS sequences suggests lability in reproductive characters. Molecular Phylogenetic and Evolution, 33 (1): 127-139. doi: 10.1016/j. ympev.2004.04.022

Knapp S., Vorntsova M. S. \& Prohens J., 2013 - Wild Relatives of the Eggplant (Solanum melongena L.: Solanaceae): New Understanding of Species Names in a Complex Group. PLoS One, 8 (2): e57039. doi: 10.1371/journal.pone.0057039

Lester N. R. \& Niakan L., 1986 - Origin and domestication of the Scarlet Eggplant, Solanum aethiopicum, from S. anguivi in Africa. In: Solanaceae: Biology and Systematics. D'Archy W. G. (ed.). Columbia University Press, Columbia: 431-456.

McNeill J., Barrie F. R., Buck W. R., Demoulin V., Greuter W., Hawksworth D. L., Herendeen P. S., Knapp S., Marhold K., Prado J., Prud'Homme van Reine W. F., Smith G. F., Wiersema J. H. \& Turland N. J. (eds.), 2012 - International Code of Nomenclature for algae, fungi, and plants (Melbourne Code) adopted by the Eighteenth International Botanical Congress Melbourne, Australia, July 2011. Regnum Vegetabile, 154: $1-240$.

Mort M. E., Randle C. P., Kimball R. T., Tadesse M. \& Crawford D. J., 2008 - Phylogeny of Coreopsideae (Asteraceae) inferred from nuclear and plastid DNA saequences. Taxon, 57 (1): 109-120.

Mouillefert P., 1892 - Traité des arbres \& arbrisseaux forestiers, industriels et d'ornement cultivés ou exploités en Europe et plus particulièrement en France donnant la description et l'utilisation de plus de 2400 espèces et 2000 variétés. Librairie des Sciences Naturelles, Paul Klincksieck, Éditeur, Paris, 1 (13): 387-416.

Plazas M., Andújar I., Vilanova S., Gramazio P., Herraiz F. J. \& Prohens J., 2014 - Conventional and phenomics characterization provides insight into the diversity and relationships of hypervariable scarlet (Solanum aethiopicum L.) and gboma (S. macrocarpon L.) eggplant complexes. Frontiers in Plant Science, 5: 318. doi: 10.3389/fpls.2014.00318

Ranil R. H. G., Prohens J., Aubriot X., Niran H. M. L., Plazas M., Fonseka R. M., Vilanova S., Fonseka H. H., Gramazio P. \& Knapp S., 2017 - Solanum insanum 
L. (subgenus Leptostemonum Bitter, Solanaceae), the neglected wild progenitor of eggplant (Solanum melongena $\mathrm{L}$.): a review of taxonomy, characteristics and uses aimed at its enhancement for improved eggplant breeding. Genetic and Resources and Crop Evolution, 64 (7): 1707-1722. doi: 10.1007/s10722-016-0467-z

Rehder A., 1922 - New species, varieties and combinations from the herbarium and collections of the Arnold Arboretum (continued). Journal of the Arnold Arboretum, 3 (1): 11-51.

Romaschenko K., Peterson P. M., Soreng R., GarcíaJacas N. \& Susanna A., 2010 - Phylogenetics of Stipeae (Poaceae: Pooideae) based on plastid and nuclear DNA sequences. In: Diversity, phylogeny and evolution in the Monocotyledons. Seberg O., Petersen G., Barfod A. S. \& Davis J. I. (eds.). Aarhus University Press, Aarhus: 513-539.

Romaschenko K., Peterson P. M., Soreng R. J., García-Jacas N., Futorna O. \& Susanna A., 2012 - Systematics and evolution of needle grasses (Poaceae: Pooideae: Stipeae) based on analysis of multiple chloroplast loci, ITS, and lemma micromorphology. Taxon, 61 (1): 1844.

Soreng R. J., Peterson P. M., Romaschenko K., Davidse G., Zuloaga F. O., Judziewicz E. J., Filgueiras T. S., Davis J. I. \& Morrone O., 2015 - A worldwide phylogenetic classification of the Poaceae (Gramineae). Journal of Systematic Evolution, 53 (2): 117-137. doi: $10.1111 /$ jse. 12150

Soreng R. J., Peterson P . M., Romaschenko K., Davidse G., Teisher J. K., Clark L. G., Barberá P., Gillespie L. J., Zuloaga F. O., 2017 - A worldwide phylogenetic classification of the Poaceae (Gramineae) II: An update and a comparison of two 2015 classifications. Journal of Systematic Evolution, 55 (4): 259-290. doi: $10.1111 /$ jse. 12262

Steudel E. T., 1840 - Nomenclator Botanicus seu: synonymia plantarum universalis, enumerans ordine alphabetico nomina atque synonyma tum generic tum specifica et a Linnaeo et a recentioribus de re botanica scriptoribus plantis phanerogamis imposita. Ed. 2. Typis et sumtibus J. G. Cottae, Stuttgartiae, Tubingae, 1 (4): 385-512. doi: 10.5962/bhl.title.655

Strother J. L., 2006 - Coreopsis Linnaeus. In: Flora of North America North of Mexico. Flora of North America Editorial Committee (ed.). Oxford University Press, New York, Oxford, 21: 185-198. 